\title{
Väitöskirja kielitiedon opettamisesta
}

Kaisu Rättyä: Kielitiedon didaktiikkaa. Kielentäminen ja visualisointi sanaluokkien ja lauseenjäsenten opetusmenetelminä. Kasvatustieteellisiä tutkimuksia 1. Helsinki: Helsingin yliopisto 2017. $208 \mathrm{~s}$.

ISBN 978-051-51-2860-7.

Kaisu Rättyän väitöskirja Kielitiedon didaktiikkaa: Kielentäminen ja visualisointi sanaluokkien ja lauseenjäsenten opetusmenetelminä käsittelee kielitiedon opetusta opettajankoulutuksessa ja perusopetuksessa. Aiheen valintaa voi luonnehtia tervetulleeksi tilanteessa, jossa koulujen kielitiedon opetusta pedagogisine ratkaisuineen ja oppimateriaaleineen on kritisoitu jo vuosia. Kritiikki on kohdistunut erityisesti kielitiedon ja kieliopin opetuksen eriytymiseen omaksi irrallisesti opittavaksi osa-alueekseen. Näin siitä huolimatta, että jo vuonna 1899 Raitio ja Niemi linjasivat Äidinkielen opetusopissaan: "Äidinkielenopetus kansakouluissa pääasiallisesti käsittää a) puhumis-, b) lukemis- ja c) kirjoitusharjoituksia, joita kaikkia, mutta erittäinkin kirjoitusharjoituksia d) kieliopin opetus tukee ja ohjaa" (Raitio \& Niemi 1899: 5). Reilut sata vuotta myöhemmin Leiwon (2003) mukaan kielitiedon ja kieliopin opetuksessa tulisi päästä nimeämisestä ja mekaanisesta sääntöjen opettelusta kielitiedon problematisointiin ja soveltamiseen sekä merkitysten vertailuun ja pohdiskeluun (ks. myös Korhonen \& Alho 2006). 2010-luvulla kielitietoonkin kytkeytyvä kielitietoisuus on nostettu perusopetuksen opetussuunnitelmassa (OPH 2014) yhdeksi koulujen toimintakulttuuria ohjaavaksi periaatteeksi. Opetussuunnitelman mukaan kielitietoisessa yhteisössä keskustellaan kieliin ja kieliyhteisöihin kohdistuvista asenteista ja ymmärretään kielen keskeinen merkitys oppimisessa, vuorovaikutuksessa sekä identiteettien rakentumisessa ja yhteiskuntaan sosiaalistumisessa (mts. 28).

\section{Kielitiedon pedagogiikkaa uudistamassa}

Kaisu Rättyän väitöstutkimuksen tavoitteena on kehittää uusia opetusmenetelmiä kielitiedon opetukseen ja lisätä tutkimuspohjaisesti ymmärrystä siitä, miten kielitietoa opetettaisiin mielekkäästi. Rättyän väitöskirja koostuu yhteenveto-osasta ja viidestä tutkimusartikkelista. Kolme ensimmäistä artikkelia keskittyy kielentämiseen ja visualisointiin opettajankoulutuksen kontekstissa (Rättyä 2013, 2014, 2015a), neljännessä artikkelissa tarkastellaan toiminnallista kielitiedon opetusta ja kielentämistä (Rättyä 2015b), ja viidennessä artikkelissa fokus on kielitiedon ja tekstitaidon opetuksen integroimisessa kahdeksannella luokalla (Rättyä \& Vaittinen 2015). Artikkeleista kolme on suomenkielisiä, yksi ruotsinkielinen ja yksi englanninkielinen. Artikkeliväitöskirjan monikielisyys heijastelee oivallisesti tutkijan kielellistä repertuaaria ja kielten luontevaa limittäistä käyttöä (ks. myös. Blackledge, Creese \& Takhi 2013).

Rättyä asemoi väitöstutkimuksensa ainedidaktisen tutkimuksen alalle, erityisesti äidinkielen ja kirjallisuuden ainedidaktiikkaan ja perustelee tätä valintaa tarkoituksenmukaisesti. Tutkimusta taustoitetaan opettajan tiedonalojen mallilla (ks. Grossman 1990) sekä tutkimuskirjallisuudella opettajien ja opettajaopiskelijoi- 
den kieliopin ja kielitiedon käsityksistä ja metalingvistisestä tiedosta. Kaikkiaan tutkimusta motivoi ajatus kielitiedon opettamisesta tavalla, joka tukee oppimista ja ymmärtää opiskelijoita ja heidän ajatteluaan. Tämä on tutkimuksen ehdoton ansio. Lukija jää kuitenkin pohtimaan, olisiko kielentämistä koskevaa käsitepohdintaa voinut syventää esimerkiksi käsittelemällä kollaboratiivista dialogia, kun ottaa huomioon tutkimuksen yhteyden oppimiseen ja opettamiseen. Tutkimuksessahan kielentämisellä oli useita tehtäviä, sillä sen avulla kerättiin tutkimusaineistoa ja saatiin opettajia ja tutkijoita hyödyttävää tietoa opettajaopiskelijoiden ja oppilaiden metakielen hallinnasta. Kielentämisen avulla myös opetettiin ja opittiin kielitietoutta.

Käsitepohdinnan syventämistä olisivat puoltaneet myös tutkimuksen oppimisteoreettiset lähtökohdat - erityisesti sosiokonstruktivistinen ja sosiokulttuurinen oppimiskäsitys -, jotka sopivat erinomaisesti tutkimuksen keskeisten käsitteiden kielentämisen ja visualisoinnin tarkasteluun. Sosiokulttuurisesti tarkasteltuna oppijan omat aikaisemmat tiedot, käsitykset ja kokemukset opittavasta asiasta säätelevät sitä, millaisia havaintoja ja tulkintoja hän tekee. Oppimisen kannalta olennaista on opittavaan asiaan liittyvien kysymysten herääminen, kokeileminen, ongelmanratkaisu, ymmärtäminen sekä kognitiivisen toiminnan sosiaalinen luonne eli uusien asioiden oppiminen vuorovaikutuksessa (Vygotsky 1982). Käytännön opetustyön ja pedagogisten valintojen näkökulmasta mielenkiintoista onkin, miten kielitiedon opetus herättäisi aitoa kiinnostusta kieleen ja kielenkäyttöön, omien ja toisten kielellisten valintojen havainnointiin ja ymmärtämiseen.

\section{Kohti ymmärtävää ja soveltavaa kielitiedon oppimista}

Väitöskirjan lähestymistavaksi Rättyä on valinnut kehittämistutkimuksen, ja se sopiikin erinomaisesti käsillä olevaan tutkimusasetelmaan, sillä tekijä on myös opettajankouluttaja ja tutkimuskontekstina on koulun lisäksi opettajankoulutus. Kehittämistutkimusta taustoitetaan ja sen valintaa lähestymistavaksi perusteellaan monipuolisesti argumentoiden ja tutkimustehtävään sitoen. Yhteenvetoosaan kootut tulokset antavat tietoa luokanopettajaopiskelijoiden ja yläkoulun oppilaiden kielitiedon hallinnasta. $\mathrm{Ne}$ myös haastavat kiinnostavalla tavalla pedagogisia käytänteitä. Opettajaopiskelijoiden ja yläkoululaisten metakielen käytön vähäisyys, lauseenjäsennykseen ja sanaluokkiin liittyvien käsitteiden sekoittuminen toisiinsa tai vain peruslauseenjäsenten tunteminen eivät sinällään ole tuloksina yllättäviä, mutta ne vahvistavat eri kouluasteilla toimivien opettajien arkihavaintoja sekä aikaisempia tutkimustuloksia (esim. Tainio \& Routarinne 2012; Kauppinen, Tarnanen \& Aalto 2014). Tulokset opiskelijoiden keskinäisen yhteistyön ja visualisoinnin suotuisasta vaikutuksesta kielitietoa aktivoivissa tehtävissä ovat puolestaan kiinnostavia kielitiedon opetuksen kehittämisen näkökulmasta.

Osatutkimusten tulosten koonnin jälkeen yhteenveto-osassa selvitellään omissa luvuissaan työn päkäsitteitä: kielentämistä, visualisointia ja käsitteellistä muutosta. Luvut syventävät käsitteiden tarkastelua, mutta ne hiukan myös sirpaloivat kokonaisuutta. Rättyä nostaa tulosten pohjalta asiantuntevasti esiin kielitiedon käsitteisiin, opetusmenetelmiin ja oppimateriaaleihin liittyvän problematiikan. Ratkaisuehdotukset ja tulevaisuuden kielitiedon opetuksen visiointi jäävät kuitenkin jatkotutkimuksen aiheiksi.

\section{Lopuksi}

Kokonaisuutena Rättyän väitöstutkimus on hyvin hallittu ja jäsennelty. Käsikirjoitus etenee selkeästi, sillä metateksti, tiivistelmät ja kuviot ohjaavat lukijaa. Koska 
kehittämistutkimukseen kuuluu toiminnan kehittäminen, väitöstutkimuksen tulokset ovat sellaisenaan hyödynnettävissä suomen kielen ja kirjallisuuden opetuksessa. Tutkivan opettajankouluttajan ansiona on läpi työn välittyvä pedagoginen innostus, hyvä opetuskontekstin tuntemus sekä opetuskokemus.

Rättyän väitöskirja on mukana rakentamassa ja ylläpitämässä keskustelua kielitiedosta ja kielitietoisuudesta. Kielitietoisuudella on juuri nyt aikansa ja paikkansa, sillä se on näkyvästi esillä perusopetuksen opetussuunnitelmassa ja keskustelua koulujen monikielisyydestä ja kielellistä repertuaareista käydään muidenkin kuin kieliasiantuntijoiden keskuudessa. Kielitietoa voidaan toki tarkastella ja määritellä useista eri näkökulmista, mutta jos ymmärrämme kielitiedon tiedoksi kielestä ja tietoiseksi ymmärryksesi siitä, kuinka kieli toimii ja kuinka ihmiset käyttävät sitä, tulemme lähelle kielitietoisuuden määritelmiä (esim. Hawkins 1984). Kysymykseksi tutkijoille ja pedagogeille jää, miten herätämme kiinnostusta ja innostusta kieleen. Senhän pitäisi olla periaatteessa helppo juttu, koska meillä kaikilla on kokemusta kielistä, niiden käytöstä ja oppimisesta eikä kokemuksellisuutta tarvitse herätellä opiskelijoissa keinotekoisesti.

Mirja Tarnanen etunimi.sukunimi@jyu.fi

\section{Lähteet}

Blackledge, Adrian - Creese, AngeLA - TAKHi, JASPREET KAUR 2013: Beyond multilingualism. Heteroglossia in practice. - Stephen May (toim.), The multilingual turn. Implications for SLA, TESOL and bilingual education $\mathrm{s}$. 191-215. London: Routledge.

Grossman, Pamela 1990: The making of a teacher. Teacher knowledge and teacher education. New York: Teachers College
Press.

HAW KINS, ERIC. 1984: Awareness of language. An introduction. Cambridge: Cambridge University Press.

Kauppinen, Merja - Tarnanen, Mirja - Aalto, Eija 2014: "Voisin pyytää oppilaita alleviivaamaan kaikki adjektiivit". Luokanopettajaopiskelija kielitietoisen aineenoppimisen ohjaajana. - Maarit Mutta, Pekka Lintunen, Ilmari Ivaska ja Pauliina Peltonen (toim.), AFinLA-e. Soveltavan kielitieteen tutkimuksia 7/2014 s. 81-10o. http://journal.fi/afinla/issue/ view/3142.

Korhonen, Rittta - Alho, Irja 2006: Kielioppia kieliopin vuoksi. - Minna Harmanen ja Mari Siiroinen (toim.), Kielioppi koulussa s. 71-92. Äidinkielen opettajain liiton vuosikirja XLX. Helsinki: Äidinkielen opettajain liitto.

Leino, Matti 2003: Addenda errata. Kirjoituksia äidinkielen kielitiedosta. Jyväskylän yliopisto: kielten laitos.

$\mathrm{OPH}=$ Perusopetuksen opetussuunnitelmien perusteet. Helsinki: Opetushallitus 2014.

Raitio, Konstantin - Niemi, HermanNI 1899: Äidinkielen opetusoppi. Kansakoulu- Y. M. alkeisopetuksen tarpeeksi. Porvoo: Werner Söderström.

RÄTtYÄ, KAISU 2013: Languaging and visualisation method for grammar teaching. A conceptual change theory perspective. - English Teaching. Practice and Critique 12 s. 87-101. 2014: Luokanopettajaopiskelijoiden metakielen käyttö kielennys- ja visualisointitehtävissä. - Eija Yli-Panula, Harry Silfverberg ja Elina Kouki (toim.), Opettaminen valinkauhassa. Ainedidaktinen symposiumi Turussa 15.3.2013 s. 19-34. Ainedidaktisia tutkimuksia 7. Turku: Turun yliopisto.

__ 2015a: Språkliggörande och visualisering som metoder för begreppsundervisning. - Arne Amdal, Henning Fjørtoft ja Tale Guldal (toim.), Faglig kunnskap i skole og loererutdanning II s. 13-31. Nordiske 
bidrag til fagdidaktikken. Bergen: Fag-

bokforlaget.

_ 2015b: Kielitiedon opetusmenetelmien uudet suunnat. Toiminnallinen kielioppi ja kielentäminen. - Teppo Jakonen, Juha Jalkanen, Terhi Paakkinen ja Minna Suni (toim.), Kielen oppimisen virtauksia.

Flows in language learning s. 187-207.

AFinLAn vuosikirja 2015. Suomen soveltavan kielitieteen yhdistyksen julkaisuja n:o 73. Jyväskylä: Suomen soveltavan kielitieteen yhdistys. http://ojs.tsv.fi/ index.php/afinlavk/artivle/view/49401.

RÄttrÿ, KAIsU - VAittinen, Pirjo 2015:

Kahdeksasluokkalaiset käyttämässä kieliopin käsitteitä. - Merja Kauppinen, Matti Rautiainen ja Mirja Tarnanen (toim.),
Elävä ainepedagogiikka. Ainedidaktiikan symposium Jyväskylässä 13.-14.2.2014 s. 192-208.. Ainedidaktisia tutkimuksia 9. Jyväskylä: Jyväskylän yliopisto.

Tainio, LiIsa - Routarinne, SARA 2012: Kieliopin ymmärtäminen ja kieliopillinen ajattelu. Luokanopettajaopiskelijat lausetta hahmottamassa. - Päivi Atjonen (toim.), Oppiminen ajassa - kasvatus tulevaisuuteen s. 249-265. Kasvatusalan tutkimuksia 61. Jyväskylä: Suomen Kasvatustieteellinen Seura.

Vygotsky, Lev Semjonovitš 1982. Ajattelu ja kieli. Suomentaneet Klaus Helkama ja Anja Koski-Jännes. Espoo: Weilin \& Göös.

\section{Viittomakielisten vanhempien kuulevien lasten kaksikielisyyden kehitys}

\section{Laura Kanto: Two languages, two mo- dalities. A special type of early bilingual language acquisition in hearing children of Deaf parents. Acta Universitatis Ouluensis B 141. Oulu: Oulun yliopisto 2016. Johdan- to $126 \mathrm{~s}$. ja kolme artikkelia. ISBN 978-952-62-1177-0 (PDF).}

Laura Kannon logopedian alan väitöskirja käsittelee tieteellisesti ja yhteiskunnallisesti ajankohtaista tutkimusaihetta, kaksikielisyyttä, ja erityisesti kaksikielisyyden varhaista kehitystä ensimmäisinä elinvuosina. Kannon tutkimuskohteena on erityinen kaksikielisyyden laji: hän tutkii suomalaisen viittomakielen ja puhutun suomen kielen kehitystä lapsilla, jotka ovat kuulevia mutta joilla ainakin toinen vanhemmista on viittomakielinen kuuro. Kyseessä on siten bimodaalinen, kaksikanavainen, kaksi- kielisyys, jossa omaksuttavat kielet hyödyntävät kahta eri aistia, näköä ja kuuloa. Kaksikanavaista kaksikielisyyttä on kansainvälisesti tutkittu varsin vähän, ja silloinkin lähinnä muutaman lapsen tapaustutkimuksina (esimerkiksi Petitto, Katerelos, Levy, Gauna, Tétreault \& Ferraro 2001; Lillo-Martin, de Quadros, Chen Pichler \& Fieldsteel 2014). Lisäksi varhaisemmat laajemmilla aineistoilla tehdyt tutkimukset ovat tarkastelleet vain puhutun kielen kehitystä ja erityisesti sen puutteita huomioimatta viittomakieltä (esim. Schiff \& Ventry 1976). Kymmenen lapsen kaksikielisen kielenkehityksen seurantatutkimuksena Kannon tutkimus on laajempi kuin aiemmat kansainväliset tutkimukset. Suomessa tutkimus on ilmeisesti ensimmäinen, joka käsittelee kuurojen vanhempien kuulevien lasten molempien kielten kehitystä. Jo täs- 